\title{
PuRCHASE MONEY SECURITY INTEREST REFINANCING IN NEW ZEALAND: A CASE FOR RETENTION OF SUPER-PRIORITY
}

\author{
Arielle Tracey*
}

This article concerns the issue of purchase money security interest (PMSI) refinancing. Under current law, PMSI super-priority is lost on refinance regardless of whether the refinancier is the original PMSI holder or a third party financier. This article contends that such a position is uncommercial and frustrates the undergirding objective of the law of debt security to facilitate the provision of credit to business. This position is supported by theory, international treatment of the issue and policy.

\section{INTRODUCTION}

A purchase money security interest, generally known as a PMSI, is a privileged form of security interest recognised by the Personal Property Securities Act 1999 (PPSA). PMSIs are privileged because, in defined circumstances, they enable a creditor's security interest to take priority over prior registered security interests (ie non-PMSI) in the same collateral. ${ }^{1}$ This privilege is called "superpriority" and represents an exception to the "first to register" priority rules contained in s 66 of the PPSA. ${ }^{2}$ The central issue addressed by this article is to ask whether that super-priority obtained under a PMSI should be preserved when an original purchase money loan is refinanced, and regardless of whether the refinance is provided by the original PMSI holder or a new financier.

This article suggests that New Zealand law should recognise a refinancier's right to super-priority. Granting a refinancier super-priority is not prejudicial to prior registered secured parties; it blunts the situational advantage obtained by prior registered secured parties; it is consistent with treatment of

* Originally submitted for the LLB (Honours) Degree, Faculty of Law, Victoria University of Wellington, 2019. My gratitude to Victoria Stace for her diligent and nurturing supervision of this paper.

1 Personal Property Securities Act 1999 [PPSA], ss 73-75.

2 Linda Widdup Personal Property Securities Act: Concepts in Practice (4th ed, LexisNexis, Wellington, 2016). 
the issue in Canada, the United States of America and Australia; and, fundamentally, is consistent with the PPSA's primary objective of facilitating the provision of credit to business.

Part II introduces the law in New Zealand. Part III explains the legislative purpose behind PMSI super-priority. Part IV surveys the relevant comparative law in Australia, Canada and the United States. Part V contends that a legislative amendment of ss 16 and 73-75 of the PPSA is the best method of recognising a refinancier's legitimate right to super-priority.

\section{THE SITUATION UNDER CURRENT NEW ZEALAND LAW}

\section{A Illustration of the Problem}

To illustrate the refinancing situation contemplated, consider the following scenario:

At Time 1, Secured Party One (SP1) takes a security interest in a Vehicle-Hire Company's (the Debtor's) all present and after-acquired property (ALLPAAP) under a General Security Agreement (GSA) which is immediately registered on the Personal Property Securities Register (PPSR).

At Time 2 (say, six months later), Asset Finance Company 1 (AF1) finances the debtor's purchase of 20 new vehicles. As the vehicles are held for lease, the fleet represents "inventory" as defined in s 16 of the PPSA. AF1 registers their security interest as a PMSI on the PPSR at the time (or before) the debtor obtains possession of the fleet and by doing so, gains priority for its security interest over SP1.

At Time 3 (say, one year later than Time 2), Asset Finance Company 2 (AF2) advances funds to the Debtor to pay out the debt to AF1 and takes a security interest in the 20 vehicles.

At current law, AF2's priority depends on whether the transaction between the Debtor and AF2 satisfies the definition of "purchase money security interest" in s 16 and qualifies for super-priority under s 74. As we will see, both elements were interpreted by the High Court in New Zealand Bloodstock Leasing Ltd v Jenkins as generally negating a refinancer's entitlement to super-priority. ${ }^{3}$ However, before we consider the decision in Jenkins, we will consider the elements of a valid PMSI.

\section{B Elements of a Purchase Money Security Interest (PMSI)}

A "purchase money security interest" is defined in s 16 of the PPSA as:

(i) a security interest taken in collateral by a seller to the extent that it secures the obligation to pay all or part of the collateral's purchase price; or

(ii) a security interest taken in collateral by a person who gives value for the purpose of enabling the debtor to acquire rights in the collateral, to the extent that the value is applied to acquire those rights; or

3 New Zealand Bloodstock Leasing Ltd v Jenkins [2007] 3 NZCCLR 811 (HC). 
(iii) the interest of a lessor of goods under a lease for a term of more than one year; or

(iv) the interest of a consignor who delivers goods to a consignee under a commercial consignment ...

Only paragraphs (i) and (ii) of the definition are relevant in the context of a discussion about PMSI refinance. ${ }^{4}$ These limbs of the definition contain two crucial requirements that must be met for a creditor to qualify for PMSI status. The first element is the transaction objective, that credit must secure the obligation to pay all or part of the collateral's purchase price or give value for the purpose of enabling the debtor to acquire rights in the collateral. The second element is the traceability requirement, that the credit extended must be traceable to an identifiable, discrete item of property. ${ }^{5}$

To secure super-priority, a creditor must also perfect its security interest in accordance with the time limits prescribed in ss 73-75. Where the security is over collateral or its proceeds but not inventory or intangibles, s 73 requires that creditors perfect their interest within 10 working days of the debtor obtaining possession. If the security is over inventory or its proceeds, both defined in s 16 , s 74 requires that creditors perfect their interest at the time (or no later than the time) that the debtor obtains possession. Perfection requires either that the secured party takes possession of the collateral or registers a financing statement. ${ }^{6}$ In the case of the types of refinancing discussed in this article, perfection will almost inevitably be achieved by registration.

\section{$C$ New Zealand Bloodstock Leasing Ltd v Jenkins}

In Jenkins, Winkelmann J held that "a new purchase money security interest could not be created by refinancing of the original debt". ${ }^{7}$ Jenkins is one case in a saga of litigation concerning the lease to purchase of a stallion named Generous. The facts may be summarised as follows:

In November 1999, prior to the enactment of the PPSA, SH Lock (New Zealand) Ltd (SHL) took a GSA over the assets of Glenmorgan Farm Ltd (Glenmorgan), representing a fixed charge over all fixed assets and a floating charge over all stock in trade.

In August 2001, New Zealand Bloodstock Leasing Ltd (NZBL), the first plaintiff, supplied Glenmorgan with a stallion, "Generous", through a lease to purchase agreement (LPA1) on retention of title terms. The defendants, shareholders of Glenmorgan, guaranteed Glenmorgan's payment obligations under LPA1.

4 In relation to purchase money security interest (PMSI) refinance, only these paragraphs have been referred to by the courts and in academic discussion.

5 Thomas H Jackson and Anthony T Kronman "Secured Financing and Priorities Among Creditors" (1979) 88 Yale LJ 1142 at 1174.

6 PPSA, s 41.

7 Jenkins, above n 3, at [58]. 
On 1 May 2002, the PPSA came into effect. SHL perfected their security interest by registering a financing statement in accordance with the transitional provisions. NZBL did not register any security interest.

In 2002, Glenmorgan began to default on its payments due under LPA1. On 28 June 2002, NZBL and Glenmorgan restructured their arrangement and entered into a second lease to purchase arrangement (LPA2). The Debtor's obligations were once again guaranteed by the defendants.

On 28 June 2002, NZBL assigned all of its rights and obligations under LPA2 to New Zealand Bloodstock Finance Ltd (NZBF), the second plaintiff.

Glenmorgan continued to default on the payments due under LPA2. On 22 August 2003, NZBF agreed to refinance LPA2 through a Refinance Agreement and a Contract for Current Advances under which funds were made available on an on-demand basis sufficient for Glenmorgan to meet its obligations under LPA2.

On 6 July 2004, Glenmorgan once again defaulted and the plaintiffs took possession of Generous.

In the earlier and related case of Waller $v$ New Zealand Bloodstock Ltd, the Court of Appeal determined that SHL's security interest had priority as NZBL had an unregistered security interest. ${ }^{8}$ In Jenkins, the plaintiffs sought to enforce the guarantees given by the defendants. To avoid their obligations as guarantors, the defendants argued, inter alia, that the plaintiffs had priority to the stallion.

\section{Reasoning in Jenkins}

It was common ground that the security interest created by LPA1, being a lease for a term of more than one year, satisfied the definition of "purchase money security interest". ${ }^{9}$ If perfected, this security interest could have taken super-priority to SHL's GSA. ${ }^{10}$ It is material that NZBL failed to perfect its PMSI because it was this unperfected security interest that was later assigned to NZBF. ${ }^{11}$

The defendants initially argued that NZBF remained entitled to the priority provided by a PMSI under LPA2 because the refinance "was merely a restructuring of the existing loan". ${ }^{12}$ The defendants

$8 \quad$ Waller v New Zealand Bloodstock Ltd [2006] 3 NZLR 629 (CA).

9 Jenkins, above n 3, at [7]. The transaction could also properly be characterised as a security interest taken in collateral by the seller to the extent that it secures the obligation to pay all or part of the collateral's purchase price.

10 Jenkins, above n 3, at [7]; and Waller v New Zealand Bloodstock Ltd, above n 8, at [99].

11 Jenkins, above n 3, at [44].

12 At [54]. 
relied upon the Canadian case of Werner v Royal Bank of Canada, where the Saskatchewan Court of Queen's Bench had accepted that "[a] consolidated or new loan used to pay out an existing loan secured by a purchase-money security interest passes that interest to the lender". ${ }^{13}$ However, although open to such an argument in principle, Winkelmann $\mathrm{J}$ rejected its application in the present case, finding that the terms and effect of the transaction negatived an intention to retain the security interest created by LPA2. ${ }^{14}$

Although not argued by the defendants, the High Court then considered whether the refinancing of LPA2 through the Refinancing Agreement and Contract for Current Advances provided by NZBF, itself created a PMSI in Generous. In other words, whether a PMSI in the collateral was created through refinance.

In discussion, Winkelmann J referred to two Canadian cases which suggested that a new PMSI could be created on refinance: Battlefords Credit Union Ltd v Ilnicki and Unisource Canada Inc $v$ Laurentian Bank of Canada. ${ }^{15}$ It was observed that in Unisource, a new PMSI was found to have been created even where the loan refinanced had not initially created a PMSI. ${ }^{16}$ However, Winkelmann J criticised this observation, citing concerns raised by Gedye, Cuming and Wood that: ${ }^{17}$

Under the Ilnicki and Unisource approach [the refinancier] could claim pmsi status because its advance has allowed [the debtor] to acquire rights in the collateral that [the debtor] did not previously have. If this is correct, the potential for abuse is obvious. A financier that failed to comply with the $\mathrm{s} 73$ formalities could get a second chance by rearranging the transaction and later general financiers could hunt out existing pmsi in an attempt to improve their priority status.

Winkelmann J went on to reject the Canadian cases as inconsistent with the scheme and intent of the PPSA to give effect to transactions in accordance with their substance rather than their form, stating that: ${ }^{18}$

... when the substance of the transactions is considered, Glenmorgan acquired no more interest in the value of Generous after the refinancing than it had before. Although ultimately title in Generous may have passed to Glenmorgan, a third party creditor continued to have a security interest in Generous securing at

13 Werner v Royal Bank of Canada 2000 SKQB 338, [2000] SJ No 476 at [12].

14 Jenkins, above n 3, at [55].

15 Battlefords Credit Union Ltd v Ilnicki (1991) 82 DLR (4th) 69 (SKCA); and Unisource Canada Inc $v$ Laurentian Bank of Canada (2000) 47 OR (3d) 616 (ONCA). Both of these cases are discussed in Part IV.

16 Jenkins, above n 3, at [48]

17 Michael Gedye, Ronald CC Cuming and Roderick J Wood Personal Property Securities in New Zealand (Thomas Brookers, Wellington, 2002) at [73.4], as quoted in Jenkins, above n 3, at [57].

18 Jenkins, above n 3, at [58]. 
least as much debt as before the refinancing. The refinancing creditor has not increased the asset pool of the company.

However, as will be explained in Part III, a requirement that the PMSI expand the debtor's asset pool is just one justification for PMSI super-priority.

Winkelmann $\mathrm{J}$ also noted the perfection requirements were an obstacle to the creation of PMSI super-priority. As the stallion was collateral, the PMSI had to be perfected in accordance with s 73 . In Winkelmann J's view, perfection was impossible as the collateral "had been in the possession of Glenmorgan well in excess of ten working days before the refinancing". ${ }^{19}$ However, as will be explained in Part IV, alternative approaches to perfection interpretation have been adopted in Canada and Australia.

\section{Discussion of Jenkins}

At first blush, the decision in Jenkins appears to close the door on the preservation of PMSI superpriority on refinance all together. However, three alternative interpretations of the decision may be suggested.

One interpretation is that PMSI super-priority can be retained under restructure. However, to secure super-priority, the restructure would need to be performed by the original PMSI holder where the overall effect of the transaction reflects an intention to retain the original agreement. ${ }^{20}$

A second interpretation is that PMSI super-priority is attainable on refinance but only where the refinance transaction enables the debtor to expand their asset pool. Winkelmann $\mathbf{J}$ suggests that a "substance over form" approach to PMSI interpretation requires that "value" in para (ii) of the definition of "purchase money security interest" should be interpreted as requiring new money which has the effect of expanding the debtor's asset pool. Where this is satisfied by a refinancing transaction, super-priority may be retained. However, questions still remain as to whether the PMSI would be over the entirety of the transaction or would only cover the newly added value. It is also uncertain whether this would apply to third party refinanciers or to the original PMSI holder only.

A third interpretation is that PMSI super-priority is still attainable, but only where the original PMSI was perfected. This argument relies upon a narrow interpretation of Jenkins which restricts it to its facts. It may be that courts will be open to the preservation of a perfected PMSI interest on refinance, but not their creation where the original PMSI was not perfected. Such an interpretation is consonant with the policy concerns articulated by Gedye, Cuming and Wood. ${ }^{21}$

19 At [59].

20 See Winkelmann J's discussion of restructure in Jenkins, above n 3, at [55].

21 Gedye, Cuming and Wood Personal Property Securities in New Zealand, above n 17, at [73.4]. 
However, interpretations two and three still confront the obstacle of the ss $73-75$ temporal requirements for perfection. Unless a hypothetical refinance of a PMSI in collateral occurs within 10 days of the debtor acquiring original possession (with the exception of an assignee), it appears that super-priority will be lost. Overall, the result for refinance stakeholders is an uncertain one.

\section{The Commercial Consequences of Jenkins}

As a matter of strict statutory analysis, it is difficult to disagree with the correctness of the Jenkins judgement. ${ }^{22}$ However, the decision is troubling for the commercial community for several reasons. First, by not recognising the automatic preservation of super-priority on refinance, refinanciers are left vulnerable to prior-secured parties. Secondly, and in consequence to the aforementioned concern, financiers may be less likely to offer refinance, reducing debtors' effective options for finance. ${ }^{23}$

Many, however, would argue that it is not a problem that PMSI super-priority is not automatically preserved on refinance. After all, the refinancier (AF2) can attain super-priority through taking an assignment of the original PMSI from AF1 under s $87,{ }^{24}$ or through subordination arrangements, such as a Deed of Priority, with the bank (SP1) under s 70.

Section 87 enables the consensual assignment of security interests. Under s 69, transferred security interests retain their priority at the date of transfer. Therefore, if AF1's PMSI were perfected at the date of transfer, as a transferee, AF2 would secure super-priority. However, in reality, AF1 is unlikely to assign its interest because, in so doing, it would lose business.

Alternatively, AF2 could seek consent from SP1 to subordinate their security interest. ${ }^{25}$ Section 70 provides a mechanism whereby secured parties may subordinate their interests to other parties. However, it is highly unlikely that the bank will subordinate its interest to AF2 because it has no commercial incentive to do so. ${ }^{26}$ Furthermore, organising a Deed of Priority with the bank may be complex if approval is required from senior staff up the chain of authority. As Neil Booth of Toyota

22 In fact, there has been very little academic or judicial discussion of the case, indicating a general acceptance of the decision.

23 Similar concerns have been raised by Robert M Lloyd "Refinancing Purchase Money Security Interests" (1985) 53 Tenn L Rev 1; Richard H Nowka "Allowing Dual Status for Purchase-Money Security Interests in Consumer-Goods Transactions" (2011) 13(1) Tenn J Bus L 13; Bernard A Burk "Preserving the Purchase Money Status of Refinanced or Commingled Purchase Money Debt" (1983) 35 Stan L Rev 1133; Working Group of the Canadian Conference on Personal Property Security Law (CCPPSL) Report to the Canadian Conference on Personal Property Security Law: Proposals for Changes to the Personal Property Security Acts (June 2017) at 25-26; and Anthony Duggan "Recent PPSA Reform Initiatives in Canada" (paper presented to Commonwealth Law Conference, Melbourne, 21-24 March 2017) at 4.

24 Indeed, Winkelmann J mentioned this in Jenkins, above n 3, at [55] in her discussion of restructure.

25 For example AF2 may include, as a term of its lending, that the bank subordinate its interest.

26 Ian Gault and others Gault on Commercial Law (looseleaf ed, Thomson Reuters) at [PS4]. The indirect commercial benefit to the bank in the debtor to remaining solvent is discussed in Part III(C). 
Financial Services explained to the author, this process is time-consuming and often can exceed the time available to the customer and the finance company. ${ }^{27}$ Additionally, the bank may not be the only secured party ahead of you in the queue. As Booth explained: ${ }^{28}$

... the biggest problem with Deeds [of Priority] is getting everyone to agree. There may be four secured parties and we're sitting fifth [and so] to move up the list requires potentially getting four different parties to agree and that can be quite difficult... It is achieving agreement which takes time and often time exceeds what you really have to do it in.

Aware of this reality, AF2 is unlikely to rely on s 70 to protect its interests.

Without super-priority, AF2's security interest sits behind the interests of prior-secured parties. AF2 is thus left exposed in the event that the debtor goes insolvent and may be deterred from offering refinance in the absence of automatic preservation of super-priority. As Booth explains, risk-averse financiers will only perform PMSI refinance: ${ }^{29}$

After you have done a whole lot of financial analysis and you know they are credit-worthy and you know they are not going into trouble. But if [the debtor] were marginal, then there is the possibility that a

liquidator could be appointed and you don't have the security you want.

This article suggests that this outcome leads to a form of creditor lock-in whereby the debtor's effective options for new credit are limited to incumbent creditors. This is uncommercial for both refinanciers and debtors as it acts as a barrier to the flow of credit. As Booth summarises, "the net outcome at the moment is that the consumer is disadvantaged". ${ }^{30}$

To deepen our understanding of the commercial imperatives of PMSI super-priority, Part III will explore two theories which explain the legislative justification of PMSI super-priority as an exception to the default priority rules in s 66.

\section{THE JUSTIFICATION FOR PMSI SUPER-PRIORITY}

The PPSA was enacted following the seminal 1988 report of Professor John Farrar and Mark O'Regan (now Justice O'Regan). ${ }^{31}$ The report, and the subsequent legislation, was modelled upon art 9 of the Uniform Commercial Code (UCC) in the United States and legislation based on art 9 in Canada. In enacting the PPSA, legislators aimed to reform the "quagmire" of New Zealand's debt security law through a reformed substance over form approach based on security interests with a

27 Interview with Neil Booth, Risk Manager for Toyota Financial Services (the author, Auckland, 16 July 2019).

28 Booth, above n 28.

29 Booth, above n 28.

30 Booth, above n 28.

31 John H Farrar and Mark A O'Regan Reform of Personal Property Security Law (NZLC PP6, 1988). 
uniform set of rules for determining priority. ${ }^{32}$ Also central to the scheme was a commercial objective of facilitating the provision of credit to enable commerce to proceed expeditiously. ${ }^{33}$ PMSIs sit within this scheme as an exception to the general priority rules under s 66. In this section, we will consider two theories which explain the justifications for PMSI super-priority: "New Money Theory" (NMT) and "Situational Monopoly Rule" (SMR).

\section{A New Money Theory}

The relevant paragraphs of the definition of "purchase money security interest" provide that a creditor's loan must enable the debtor to acquire rights in the collateral, ${ }^{34}$ or secure the obligation to pay all or part of the collateral's purchase price. ${ }^{35}$ These elements describe circumstances where the creditor's loan makes possible the debtor's interest in assets. ${ }^{36}$ NMT holds that it is this enabling function of the loan, which confers special benefits upon the debtor, that the law recognises as justifying super-priority. ${ }^{37}$ There are two branches to NMT, the dynamic and the static.

According to dynamic NMT, the PMSI-holder deserves super-priority because their loan enabled the debtor to purchase new assets. ${ }^{38}$ The acquisition of the new assets is attributed with having increased the profitability of the debtor's business by improving efficiency in the case of collateral and increasing sales in the case of inventory. ${ }^{39}$ In turn, increased profitability is seen as reducing the debtor's risk of default and, in this sense, makes competing secured creditors better off. ${ }^{40}$ As stated by Farrar and O'Regan, "[t]he rationale of ... [super-priority] is that ... the creditor is augmenting the debtor's estate." ${ }^{41}$ It is possible to see Winkelmann J's requirement that the refinance transaction have the effect of expanding the debtor's asset pool as putting emphasis on the dynamic interpretation of NMT. $^{42}$

However, according to static NMT, new money may be valued even where the loan simply enables the debtor to retain assets. According to the static understanding, the PMSI-holder deserves

32 Law Commission A Personal Property Securities Act for New Zealand (NZLC R8, 1989) at [6].

33 Farrar and O'Regan, above n 31, at 11; and Law Commission, above n 32, at 7.

34 PPSA, s 16(i).

35 PPSA, s 16(ii).

36 Jackson and Kronman, above n 5, at 1165-1175.

37 Anthony Duggan "Romalpa Agreements Post-PPSA" (2011) 33 Syd L Rev 645 at 652.

38 At 653.

39 At 652 .

40 At 652.

41 Farrar and O'Regan, above n 31, at 69.

42 Jenkins, above n 3, at [58]. 
super-priority because, even if the new money does not make competing secured parties better off, the PMSI transaction at least does not make them worse off. ${ }^{43}$ What both the dynamic and static versions of NMT share is an understanding of the inherent "fairness" 44 of giving a first claim to assets to those who parted with their money to make possible the acquisition, or continued holding, of assets.

\section{B Situational Monopoly Rule}

By contrast, SMR seeks not to reward PMSI creditors, but to protect them. To explain SMR requires an appreciation of the link between super-priority and the PPSA's recognition of security interests in after-acquired property under s $43 .{ }^{45}$ If we recall the relevant parts of the definition of "purchase money security interest" in s 16 , qualification requires that a creditor provide a loan which enables the debtor to acquire rights in the collateral. As a rule, situations where the debtor already owns the property will not qualify. The corollary is that the only circumstances where PMSI property will be subject to competing security interests is if prior-secured creditors included an after-acquired property clause (ALLPAAP) in their agreement with the debtor. ${ }^{46}$ The effect of an ALLPAAP clause is that the relevant security interest will automatically extend, with the same priority, to encompass assets which subsequently become part of the debtor's asset base. ${ }^{47}$

SMR contemplates that if priority were only determined by s 66 , all prospective financiers would automatically be subordinated to creditors with previously perfected security interests. This reflects the residual rule in s 66(b) that, as between perfected security interest, priority will be determined inter se by reference to the order of perfection. In such circumstances, subsequent lenders could never perfect first.

Unless the prior-secured party (SP1) agrees to subordinate their security interest in relation to the PMSI assets to the prospective financiers (an unlikely proposition) financiers will be reluctant to lend because doing so would mean taking a second-ranking security interest with less protection if the debtor goes insolvent. In the case the subsequent lender (SP2) was still willing to lend, any loan would likely be on higher interest terms to compensate for the added risk of second-tier priority. However, by increasing the interest payable, SP2 makes themselves less competitive vis-à-vis SP1 whose reduced risk enables them to offer a similar loan on lower interest terms. If SP1 offers a loan on more competitive terms then, ceterius paribus, the debtor will borrow from the SP1. ${ }^{48}$ In this scenario, the

43 Duggan "Romalpa Agreements Post-PPSA", above n 37, at 652.

44 Lloyd, above n 23, at 11

45 Widdup, above n 2, at [17.2].

46 Jackson and Kronman, above n 5, at 1165-1175.

47 PPSA, s 44.

48 Duggan "Romalpa Agreements Post-PPSA", above n 37, at 653. 
debtor experiences "creditor lock-in" wherein the incumbent lender's situational monopoly reduces the debtor's effective options to obtain fresh capital. ${ }^{49}$

SMR highlights that, without legislative intervention in the form of PMSI super-priority, the dual effect of SP1's ability to take security in after-acquired property, combined with the "first to register" rules under s 66, effectively gives SP1 a competitive advantage over subsequent secured parties to the detriment of the debtor. ${ }^{50}$ If it were not for the PMSI category, a debtor would not, as a matter of commercial feasibly, have access to finance to acquire collateral in cases where the SP1 was not willing to lend. ${ }^{51}$ By providing a special level of priority in exception to $\mathrm{s} 66$, the PPSA "blunts this situational monopoly" by facilitating borrowing from other sources, preserving the incentive for financiers to provide credit to debtors in return for super-priority security. ${ }^{52}$

\section{The Perceived Prejudice to Incumbent First-Registered Secured Parties}

Some argue that providing super-priority to PMSI creditors is prejudicial to ALLPAAP creditors who were first to register. However, the likes of SP1 are in fact no worse off than if the debtor had not entered into the PMSI agreement. ${ }^{53}$ As Darcy L Macpherson observes, this reflects three considerations. ${ }^{54}$ First, SP1 was never interested in the business of financing the debtor's acquisition of collateral or inventory. If they had been, there would have been no need for a subsequent lender in the first place. As such, the debtor would not have obtained the asset but for the credit provided for under a PMSI. ${ }^{55}$ Secondly, the service provided by the PMSI lender does not damage the position of SP1 but, in good times, may improve it. This reflects the fact that, had a PMSI transaction not enabled the debtor to increase their pool of assets, it would not have qualified as a PMSI. Thirdly, because SP1 would rank only second to the PMSI, SP1's position would gradually improve as the PMSI debt was repaid and therefore the collateral subject to the ALLPAAP expanded.

49 Burk, above n 23, at 1155 .

50 Ronald CC Cuming, Catherine Walsh and Roderick Wood Personal Property Security Law (Irwin Law, Toronto, 2005) at 330-331.

51 Roger Fenton Garrow and Fenton's Law of Personal Property in New Zealand (7th ed, LexisNexis, Wellington, 2010) vol 2 at 189.

52 Jackson and Kronman, above n 5, at 1173.

53 Farrar and O'Regan, above n 31, at 70.

54 Darcy L Macpherson "Dueling Purchase-Money Security Interests under the PPSA: Explaining the Law and Policy Behind Section 34(7)" (2012) 36 Manit LJ 383 at 388.

55 Cuming, Walsh and Wood, above n 50, at 330-331. 


\section{Consistency with Refinance}

It is suggested that providing super-priority to refinanciers is similarly not prejudicial to SP1, even in cases where the transaction does not enable the debtor to expand their asset base. This reflects two considerations: the debtors' objectives for refinancing and the fact that SP1 was always subordinate to the PMSI.

There are numerous reasons for a debtor to refinance an existing PMSI. One scenario may be where the debtor's financial position is healthy, but the debtor is incentivised to refinance because the new loan is on better terms. Alternatively, the debtor may be incentivised to refinance because they are on the brink of default and the refinanced loan is repayable over a longer duration. In either case, the refinance does not prejudice SP1, as their interests align with the debtor avoiding insolvency and possibly improves their position. The second consideration is that SP1's security interest was already subordinated to AF1's. As such, their position is unchanged if AF2 assumes the same position. As Anthony Duggan suggests, a simple change in identity should be "irrelevant". 56

Although recognition of PMSI super-priority on refinance may not be consistent with the dynamic conception of NMT, which requires the acquisition of new assets, it is consistent with the static version which applies even if the debtor's asset position remains unchanged. In circumstances where refinance enables the debtor to avoid insolvency, or secure better lending terms, this is satisfied. Additionally, recognising super-priority on refinance would blunt a quasi-situational monopoly as held by the incumbent lenders. If a debtor cannot acquire effective refinance from third party financiers, their effective choice set is reduced. As seen in the context of the wider objects of the PPSA scheme to facilitate the provision of credit, the valid commercial enterprise of refinance would be short-circuited.

Part IV explores how New Zealand's sibling jurisdictions, ${ }^{57}$ Canada, Australia, and the United States, treat the issue of PMSI refinance.

\section{COMPARATIVE LAW}

\section{A United States of America}

In 2001, all 50 states adopted a revised version of art 9 of the UCC (Revised art 9). ${ }^{58}$ One element of the reform included enhancing the position of PMSI lenders. ${ }^{59}$ Under Revised art 9, § 9-103(f)(3)

56 Anthony Duggan "Refinancing Purchase Money Security Interests: A Note on Allied Distribution Finance Pty Ltd v Samwise Holdings Pty Ltd" (2018) 36 C\&SLJ 74 at 76-77.

57 "Sibling" by virtue of the shared art 9 model.

58 Adoption after the deadline included Alabama, Florida and Mississippi on 1 January 2002 and Connecticut on 1 October 2001 .

59 Elaine A Welle "An Introduction to Revised Article 9 of the Uniform Commercial Code" (2001) 1 Wyo L Rev 555 at 597. 
expressly provides that, in a transaction other than a consumer-goods transaction, a PMSI does not lose its super-priority even if the purchase-money obligation has been "renewed, refinanced, consolidated, or restructured". ${ }^{60}$ The impetus for this revision was the confusion surrounding the previous definition of "purchase money security interest". ${ }^{61}$ As Jenna Fruechtenicht explains, prior to revision, the relevant provision ( $\$ 9-107$ ) had "spawned three different theories of [PMSI refinance] interpretation, and each has been adopted by at least one of the six federal circuit courts to have ruled on the matter". ${ }^{62}$ These theories were the Transformation Rule, Novation Theory and the Dual Status Doctrine.

\section{Transformation Rule}

According to the Transformation Rule, PMSI super-priority is irrevocably destroyed by refinancing. ${ }^{63}$ This view holds that if a security interest secures both purchase-money debt and nonpurchase-money debt, the security interest is to be treated as non-purchasing-money debt. ${ }^{64}$ Mixing the two forms of debt effectively "transforms" the security interest into a non-PMSI. This rule is based on the belief that a PMSI should only secure the purchase price of the collateral. ${ }^{65}$

\section{Novation Theory}

The second approach, Novation Theory, treats the refinancing of PMSI debt as a novation. ${ }^{66}$ Under novation, the effect of discharging the PMSI debt is to create a non-PMSI in its place (ie a new loan). ${ }^{67}$ Novation Theory applies a literal interpretation of the wording of the UCC, paying close

60 Note: Section 9-103(e) contains a carve out for consumer-goods transactions. "Consumer-goods transactions" are defined as consumer transactions in which (A) an individual incurs an obligation primarily for personal, family, or household purposes, and (B) a security interest in consumer goods secures the obligation (\$ 9102(a)(24)). The carve out is intended to leave to the court the determination of which rule to adopt for consumer-goods transactions. §9-103(h) stipulates that a court may not infer from that limitation the nature of the proper rule on consumer-good transactions and may continue to apply established approaches. Therefore, the approaches taken between, and even within, states can be divergent. Nine states (Florida, Idaho, Indiana, Kansas, Louisiana, Maryland, Nebraska, North Dakota and South Dakota) have amended § 9-103 so that the dual status applies to both commercial and consumer-goods transactions. As the focus of this article is vehicles held for hire (inventory and not consumer goods), the carve out is not discussed further.

61 Welle, above n 59, at 597.

62 Jenna Fruechtenicht "'Refinanced or Modified': Is it a PMSI? An Analysis of North Carolina's PMSI Amendment" (1994) 29 Wake Forest L Rev 915 at 915

63 Burk, above n 23, at 1133.

64 For example In re Simpson 4 UCC Rep Serv (Callaghan) 243 (WD Mich 1966) at 246-248, as cited in Lloyd, above $\mathrm{n} 23$, at $4, \mathrm{n} 12$.

65 Fruechtenicht, above n 62, at 922.

66 Lloyd, above n 23, at 4.

67 See for example In re Matthews 724 F2d 798 (9th Cir 1984), as cited in Lloyd, above n 23, at 4, n 13. 
attention to the wording of the provision and the guidance of the Official Comment. ${ }^{68}$ As previously drafted, art 9 provided that a lender's security interest will qualify as a PMSI only if the lender "by making advances or incurring an obligation gives value to enable the debtor to acquire rights in ... collateral". ${ }^{69}$ The accompanying comment explained that this language "excludes from the purchase money category any security interest taken as security for or in satisfaction of a preexisting claim or antecedent debt". ${ }^{70}$ Under novation, refinancing transactions were interpreted as loans advanced to secure antecedent debt. ${ }^{71}$ However, courts disagree as to whether novation should be "automatic" or whether evidence of the parties' intent to terminate and replace the PMSI is required. ${ }^{72}$

\section{The Dual Status Doctrine}

The third approach, Dual Status Doctrine, preserves PMSI super-priority but only with respect to the portion of the loan that the refinancier can trace back to the original PMSI loan. ${ }^{73}$ Dual status proponents rely on the phrase "to the extent" in § 9-107 in support of their argument that a single loan might have two natures - "one a purchase money nature and the other not". ${ }^{74}$ PMSI super-priority is only lost where the debt is refinanced in such a manner that it becomes impossible to determine how much of the combined debt is purchase money. ${ }^{75}$

\section{Revised art 9 and subsequent interpretations}

As Richard Nowka explains, in revising art 9, the Permanent Editorial Board for the UCC (PEB) codified dual status. $^{76}$ In other words, by clarifying that PMSI super-priority is retained notwithstanding refinance, the revision rejects both rules of Novation and Transformation in commercial dealings. ${ }^{77}$ In their report, the PEB stated that it was their belief that the revisions "would

68 In re Jones 5 Bankr 655 (Bankr MDNC 1980).

69 Uniform Commercial Code (1962), § 9-107

70 Uniform Commercial Code (1978), § 9-107 Official Comment 2, as quoted in Burk, above n 23, at 1148.

71 In re Snyder 16 Bankr 380 (Bankr SD Ohio) at 381, as cited in Burk, above n 23, at 1148.

72 Compare In re Johnson 15 BR 681 (Bankr WD Mo 1981) with In re Jones, above n 68.

73 Lloyd, above n 23, at 4.

74 David Gray Carlson "Purchase Money under the Uniform Commercial Code" (1993) 29 Idaho L Rev 793 at 823.

75 Lloyd, above n 23, at 63.

76 Nowka, above n 23, at 26; Permanent Editorial Board Study Group for the Uniform Commercial Code PEB Study Group Uniform Commercial Code Article 9 Report (1 December 1992) at 97; and Uniform Commercial Code (2001), § 9-103, Official Comment 7.

77 Welle, above n 59, at 497. The Court in In re Saxe 491 BR 244 (Bankr WD Wis 22 2013) determined that the enactment of Revised Article 9 in Wisconsin reiterated the intention of the drafters of Revised art 9 to reject "transformation doctrine". 
yield the results that obtain under a proper application of current law". For some, the phrase "proper application of current law" suggests that the language of $\S 9-107$ already permitted dual status. ${ }^{78}$

However, despite the apparently clear wording of the revision, some courts have interpreted $\S 9$ 103(f)(3) differently. For example, in Lewiston State Bank v Greenline Equipment LLC, the Utah Court of Appeals held that a PMSI could only survive refinance if the refinancier was the original PMSI holder, or an assignee of the original creditor. ${ }^{79}$ Material to this determination was the awkward fact that the original PMSI debt had been repaid more than one month before the debtor purchased the equipment. In such circumstances, there appeared to be no intention to continue the effectiveness of the original PMSI. ${ }^{80}$ However, arguably the same result could be achieved by holding that perfection of the refinanced PMSI was not effective whilst avoiding the consequence of excluding third party creditors. ${ }^{81}$

Lewiston was later applied in the Seventh Circuit Court of Appeals case, Caterpillar Financial Services $v$ Peoples National Bank. ${ }^{82}$ The Court in Caterpillar was particularly concerned that if superpriority could be secured without the refinancier first becoming the assignee of the PMSI, third parties would be misled by the apparent extinguishment of the earlier interest. ${ }^{83}$ The express rejection of Novation and Transformation reflected in the Revised art 9 appears to have been overlooked by the Court. Overall, these decisions create uncertainty as to how the code may be interpreted in future and the steps that a creditor ought to take to retain super-priority.

\section{B Canada}

\section{Canadian Conference on Personal Property Securities Law Report}

The Canadian PPSAs were modelled upon Article 9 of the UCC. However, as between provinces, drafting and interpretation can be divergent. A non-governmental body, the Canadian Conference on Personal Properties Securities Law (CCPPSL), comprised of provincial and territorial registrar representatives, ${ }^{84}$ periodically examines and, where appropriate, suggests reform to harmonise and

78 PEB Study Group Uniform Commercial Code Article 9 Report, above n 76, at 87, as cited in Nowka, above n 23 , at 27 .

79 Lewiston State Bank v Greenline Equipment LLC 147 P 3d 951 (Utah Ct App 2006) at [16].

80 At [19].

81 Nowka is also critical of the Lewiston judgment. In his view, the severe consequence of terminating superpriority should caution courts against holding that refinance constitutes a novation "unless the parties clearly indicate that intent": Nowka, above n 23, at 43 (emphasis added). See also Lewiston, above n 79.

82 Caterpillar Financial Services v Peoples National Bank 710 F 3d 691 (7th Cir 2013).

83 At 695 .

84 Namely Personal Property Security Act RSA 2000 c. P-7 (Alberta, "APPSA"); Personal Property Security Act RSBC 1996 c. 359 (British Columbia, "BCPPSA"); Personal Property Security Act CCSM c. P35 (Manitoba, "MPPSA"); Personal Property Security Act SNB 1993 c. P-7.1 (New Brunswick, "NBPPSA"); 
improve the legislation. ${ }^{85}$ Most recently, in June 2017, a CCPPSL Working Group comprised of six PPSA academics and a British Columbia government representative ${ }^{86}$ suggested changes to the Canadian PPSAs. ${ }^{87}$ One area of focus was PMSI refinancing.

The Working Group recommended that each province amend their definition of "purchase money security interest" to preserve super-priority on refinance. Every recommendation of the Working Group was ratified by the CCPPSL. ${ }^{88}$ Because the definition is nearly identical across the PPSAs, the Working Group recommended that the following phraseology be uniformly adopted: ${ }^{89}$

When refinancing [a PMSI] obligation ... occurs pursuant to a refinancing agreement between the debtor and a secured party other than the secured party who provided the credit or value referred to [above], and

(a) the original registration relating to the purchase money security interest securing the obligation is amended to identify the secured party named in the refinancing agreement as a secured party; or

(b) before expiry or discharge of the original registration relating to the security interest a registration relating to the purchase money security interest is effected disclosing the secured party named in the refinancing agreement as the secured party, or the security interest is otherwise perfected;

the purchase money security interest is deemed for priority purposes to have been assigned to the secured party who provided value to the debtor pursuant to the refinancing agreement.

This "deemed assignment approach" was considered by the Working Group to be a more desirable way to preserve super-priority than the "stretched" interpretations of the existing legislation developed in cases like Ilnicki and Unisource discussed below. ${ }^{90}$

Personal Property Security Act SNL 1998 c. P-7.1 (Newfoundland, "NFPPSA"); Personal Property Security Act SNWT 1994 c. 8 (Northwest Territories, "NWTPPSA"); Personal Property Security Act SNS 1995-96 c. 13 (Nova Scotia, "NSPPSA"); Personal Property Security Act SNWT 1994 c. 8 (Nunavut, "NPPSA"); Personal Property Security Act RSO 1990 c. P.10 (Ontario, "OPPSA"); Personal Property Security Act RSPEI 1988 c. P-3.1 (Prince Edward Island, "PEIPPSA"); Personal Property Security Act SS 1993 c. P-6.2 (Saskatchewan, "SPPSA"); and Personal Property Security Act RSY 2002 c. 169 (Yukon, "YPPSA").

85 Report to the Canadian Conference on Personal Property Security Law, above $\mathrm{n} 23$.

86 Namely Professor Clayton Bangsund (University of Saskatchewan); Professor Tamara Buckwold (University of Alberta); Cynthia Callahan-Maureen (Government of British Columbia); Professor Anthony Duggan (University of Toronto); Professor Catherine Walsh (McGill University); and Professor Roderick J Wood (University of Alberta). Professor Ron CC Cuming (University of Saskatchewan acted as editor and convener.

87 See Report to the Canadian Conference on Personal Property Security Law, above n 23.

88 Duggan "Recent PPSA Reform Initiatives in Canada", above n 23.

89 Report to the Canadian Conference on Personal Property Security Law, above n 23, at 26.

90 At 26. 


\section{Battlefords Credit Union Ltd v Ilnicki}

Ilnicki, a 1991 decision of the Saskatchewan Court of Appeal, considered whether a PMSI in farming machinery and equipment had been created through a consolidation loan. In interpreting the relevant definition of "purchase money security interest",91 Cameron and Vancise JJA adopted a "bundle of rights" approach. The Court held that the word "rights" in the sentence "a security interest taken in collateral by a person who gives value for the purpose of enabling the debtor to acquire rights in or to the collateral", would be satisfied in cases where the loan advanced by the refinancier enabled the debtor to eliminate or reduce a prior security interest. ${ }^{92}$ The Court held that super-priority could arise if the refinancier was the original PMSI creditor or a third party. ${ }^{93}$

However, Ilnicki's non-assignment approach has been criticised for conceptual inaccuracy. ${ }^{94}$ As Linda Widdup notes, "a subsequent secured party in this case will not have provided value for the purpose of enabling the debtor to acquire rights in the collateral, because the debtor already had the collateral". ${ }^{95}$ As we saw in Part II, this is the same basis upon which Winkelmann J rejected superpriority on refinance in Jenkins.

Due to the limited nature of the appeal, the issue of perfection was not determined by the Court in Ilnicki.$^{96}$ A requirement that the existing PMSI be perfected in order to secure super-priority was also not articulated by the Court. As noted in the critique by Gedye, Cuming and Wood, such a position is bad in policy. ${ }^{97}$ However, the CCPPSL Working Group's recommendations include a requirement that the original PMSI be perfected. ${ }^{98}$

\section{Unisource Canada Inc v Laurentian Bank of Canada}

Unisource, a 2000 decision of the Ontario Court of Appeal, concerned whether a PMSI had been created by the refinancing of a printing press. In interpreting the phrase "rights in or to" in the relevant

91 SPPSA, s 2 (gg)(ii).

92 Ilnicki, above n 15, at [12] reflects a static conception of New Money Theory.

93 At [12].

94 Anthony Duggan "Hard Cases, Equity and the PPSA" 34 (2001) Can Bus LJ 129 at 135.

95 Widdup, above n 2, at [17.38].

96 The issue for determination by the Court rested solely on the satisfaction of s 2(gg)(ii) of the SPPSA for the purposes of s 50 of the Farm Security Act SS 1988-1989 c S-17.1.

97 See Gedye, Cuming and Wood Personal Property Securities in New Zealand, above n 17, at [73.4]. A similar critique is noted in Ronald CC Cuming and Roderick J Wood British Columbia Personal Property Security Act Handbook (4th ed, Carswell, Toronto, 1998) at 249.

98 Report to the Canadian Conference on Personal Property Security Law, above n 23, at 26. 
definition of "purchase money security interest", 99 the Court did not adopt the Ilnicki approach and instead paid close attention to the terms of the debtor's possession of the collateral. Prior to refinancing, the debtor only had a contingent equitable interest in the collateral being an option to purchase whereas, afterwards the debtor had title to the collateral. ${ }^{100}$ The Court held that by enlarging the debtor's proprietary rights in the collateral, the refinance qualified as a PMSI. ${ }^{101}$ In the Court's opinion, such an interpretation was consonant with sound commercial policy: ${ }^{102}$

If a difference between a lease/option arrangement and the acquisition of title is recognized, it will be easier for the debtor to enter into a new financing arrangement to acquire further rights in collateral without the co-operation of the original lender being required. The debtor and its business will benefit.

In the Court's opinion, recognising the refinancier's super-priority would not be prejudicial to prior first-registered secured parties (SP1) because "it accords with the original expectation of the parties in this case that the security interest granted to [SP1] would rank second in priority". ${ }^{103}$ In fact, to hold otherwise would be to grant SP1 a windfall. ${ }^{104}$

However, Unisource has been criticised for promoting a form over substance approach to PMSI interpretation antithetical to the scheme. ${ }^{105}$ As Duggan comments: ${ }^{106}$

The objective is to facilitate refinancing transactions, but the court's solution depends on the form of the transactions in issue. It only works where the original transaction is a lease or other title retention arrangement and the second transaction is a secured loan.

In concluding that the refinancier held a valid PMSI, the Court did not articulate how perfection was satisfied. To obtain priority under the Ontario PPSA, a creditor would have to perfect its security interest within 15 working days of the debtor obtaining possession. ${ }^{107}$ Duggan suggests that the Court took a liberal interpretation of the specified periods for perfection similar to that applied in the earlier case of Farm Credit Corporation v Gannon. ${ }^{108}$ In Gannon, the Court held that the requisite time

99 OPPSA, s 1.

100 Unisource, above n 15, at [2].

101 At [14]

102 At [13].

103 At [1].

104 At [1].

105 See for example Jenkins, above n 3, at [57].

106 Duggan "Hard Cases, Equity and the PPSA", above n 94, at 132.

107 OPPSA, s 33(2).

108 Farm Credit Corporation v Gannon [1993] 6 WWR 736 (SKQB); and Duggan "Hard Cases, Equity and the PPSA", above n 94, at 130. 
period for perfection runs not from the date the debtor took possession of the collateral, but from the date the debtor came into possession in its capacity as debtor to the refinancier. ${ }^{109}$

However, Gannon conflicts with the later Nova Scotia case of MacPhee Chevrolet Buick GMC Cadillac Ltd v SWS Fuels Ltd where the Court of Appeal refused to interpret the time period in the same manner, holding that the debtor should be interpreted as "obtaining" possession for the purposes of perfection in the literal sense. ${ }^{110}$ This determination was based on several considerations. Firstly, if the legislature had intended the provision to preserve super-priority on refinance, it would have made this clear through express wording. ${ }^{111}$ Secondly, parties are able to assign their interests under the Nova Scotia PPSA. ${ }^{112}$ Having not taken advantage of this opportunity, the refinancier is not prejudiced by the court's narrow interpretation of the provision. However, as covered in Part II, one may be critical of the court's contractual freedom argument because it assumes that the original PMSI holder would be willing to assign. Lastly, a more liberal interpretation of the provision would run the risk of entitling a subsequent creditor to super-priority when the original PMSI holder, by failing to perfect their interest, had not themselves obtained super-priority. ${ }^{113}$

The CCPPSL Working Group's recommendations were developed in light of the inconsistencies between cases like Ilnicki, Unisource, and MacPhee. In its report, the Working Group states that the reforms aim to facilitate the refinancing of PMSIs whilst avoiding prejudice to incumbent secured parties. ${ }^{114}$ This is achieved by automatically deeming the original PMSI to be statutorily assigned to the refinancing secured party on a discharge of the original PMSI debt. ${ }^{115}$ Under this arrangement, super-priority can only be secured where the original PMSI had super-priority. ${ }^{116}$

Following publication of the Working Group's report in 2017, the Saskatchewan Legislature has been a first-mover in adopting the report's recommendations, passing Bill 151 into law on 12 March 2019. ${ }^{117}$ This legislative eagerness likely reflects the province's familiarity with this approach, it being the common law in Saskatchewan for 30 years under Ilnicki. Under the amendments, it is crucial that

109 Gannon, above n 108, at 9.

110 MacPhee Chevrolet Buick GMC Cadillac Ltd v SWS Fuels Ltd 2011 NSCA 35, [2011] NSJ No 194.

111 At [50].

112 NSPPSA, s 24(2).

113 MacPhee, above n 110, at [54].

114 Report to the Canadian Conference on Personal Property Security Law, above n 23, at 26.

115 At 26 .

116 Duggan "Recent PPSA Reform Initiatives in Canada", above n 23, at 6.

117 The Bill received Royal assent on 15 May 2019. 
the purchase money refinancier who seeks to rely on the deeming provision registers its security interest before the original lender discharges its registration. ${ }^{118}$

\section{Australia}

The Personal Properties Securities Act 2009 (Cth) (AuPPSA) was modelled upon both the New Zealand and Canadian regimes. ${ }^{119}$ However, s 14(5) of the AuPPSA's definition of "purchase money security interest" uniquely provides that: ${ }^{120}$

A purchase money security interest does not lose its status as such only because the purchase money

obligation is renewed, refinanced, consolidated or restructured (whether or not by the same secured party).

In 2009, the Supreme Court of South Australia considered the operation of this section in Samwise Holdings Pty Ltd $v$ Allied Distribution Finance Pty Ltd. ${ }^{121}$ The appellant in this case, Samwise Holdings Pty Ltd, argued that super-priority should not be recognised as the refinance did not provide new value to the relevant asset pool. However, Doyle J, in the majority, rejected this argument, holding that one could not reconcile an intention to confine the application of s 14(5) to situations involving new assets with the AuPPSA's apparent intention to facilitate, "if not encouraging", PMSI refinancing under s $14(5){ }^{122}$

Doyle J considered that failure to grant the refinancier super-priority "merely because the person who subsequently become the grantor of the purchase money security interest happened to have possession of the property in a different capacity", would be to allow non-purchase money holders a windfall. ${ }^{123}$ Doyle $\mathrm{J}$ agreed with the trial judge's observation that the legislature would not have intended to provide such a windfall benefit at the expense of the PMSI holder. ${ }^{124}$

As for the issue of perfection, Doyle $\mathrm{J}$ had to consider whether the reference to a grantor obtaining possession of the inventory in s 62(2)(b)(i) was a reference to the grantor obtaining possession as the grantor of the PMSI, or to the grantor obtaining possession "simpliciter". ${ }^{125}$ Analogous to Gannon,

118 Bill 151, cl 34(16)(b)(ii).

119 Australian Law Commission Personal Property Securities (ALRC Report No 64, 1993) at 3 and 6.

120 Personal Property Securities Act 2009 (Cth), s 14(5).

121 Samwise Holdings Pty Ltd v Allied Distribution Finance Pty Ltd [2018] SASCFC 95, (2018) 131 SASR 506.

122 At [103].

123 Allied Distribution Finance Pty Ltd v Samwise Holdings Pty Ltd [2017] SASC 163, (2017) 355 ALR 356 at [99], as cited in Samwise, above n 121, at [96].

124 At [30].

125 At [16]. 
Doyle J concluded that the time in s 62(2)(b)(i) should be read as meaning the time the grantor obtained possession in its capacity as grantor of the refinancier's PMSI. ${ }^{126}$

\section{Discussion}

This survey of comparative law reveals a common legislative intention across the three countries to align the recognition of a refinancier's rights to super-priority with the scheme's undergirding objective to facilitate, even encourage, the provision of credit to business. In cases like Ilnicki and Unisource, we saw the Court's willingness to "stretch" the interpretation of the legislative language to give effect to such a policy. Although one may criticise the reasoning of these cases, it is difficult to disagree with the commercial utility of their results.

By not recognising the commercial imperative of preserving super-priority, New Zealand is an outlier. This anomaly is hard to justify given the common origin, function, and objectives of the legislation across the jurisdictions discussed, and the legitimate commercial application of PMSI refinance in business.

\section{SOLUTION}

The author argues that New Zealand should recognise PMSI priority on refinance. The benefits (in particular, in encouraging the provision of credit to business through refinance) outweigh the possible risks (in particular, that rules might be used to effectively cure a non-perfected PMSI). There exist four potential ways to achieve this, three litigious and one legislative.

\section{A Litigation}

\section{Narrow interpretation}

First, as touched upon in Part II, refinanciers may be able to rely upon a narrow interpretation of Jenkins. Litigants could argue that Jenkins law does not preclude super-priority in cases where perfected PMSI are refinanced. However, a narrow interpretation of Jenkins may serve little utility for litigants who would be unlikely to overcome the obstacle of Winkelmann J's clear statements regarding perfection.

\section{Appeal}

Another method could be to appeal Jenkins. As Jenkins was a decision of the High Court, both the Court of Appeal and the Supreme Court would have discretion to depart from the decision. Arguments based upon Ilnicki or Unisource could be made to reinterpret "value" under the s 16 definition and "possession" under ss 73-74 to preserve super-priority. However, it seems unlikely that either Court would adopt such constructions in light of Winkelmann J's clear rejection of both cases in Jenkins, and academic criticism of this type of reasoning. 


\section{Equitable subrogation}

Some authors have suggested that a better approach might be for the refinancier to rely on the equitable doctrine of subrogation. ${ }^{127}$ Subrogation provides for the substitution of one party (B) for another (A) so that B assumes A's rights in respect of a claim. ${ }^{128}$ In the context of refinance, Cuming and Wood state that subrogation would allow a lender who has advanced money to pay out the prior PMSI to assert the rights of the original PMSI holder whose debt was repaid in the refinance transaction with funds from the refinance loan. ${ }^{129}$ As "subrogation is a derivative right", a refinancer would only be entitled to PMSI status if the original PMSI was perfected and maintained. ${ }^{130}$ Although the New Zealand PPSA does not contain a provision expressly preserving equitable and common law principles, Cuming and Wood suggest that subrogation would not be displaced because it is not inconsistent with the Act. ${ }^{131}$

However, because subrogation is an equitable remedy and a matter for the court's discretion, it would not give refinanciers the certainty required for commercial dealings. Furthermore, using subrogation to perform the role that legislative amendment expressly provides for in comparative jurisdictions would arguably be inconsistent with the scheme of the PPSA. As per Farrar and O'Regan, "[t]he role of law in relation to the economics of property relationships is to provide a definitive framework for those relationships to facilitate exchange and financing transactions." 132

Furthermore, both equitable subrogation and appealing Jenkins rely on individual litigants to bring the action. The cost of litigation would likely prove prohibitive. Litigation would also generally only arise in the worst case scenario of the debtor's insolvency. Commercial parties are unlikely to structure their secured dealings around such uncertain prospects. It is suggested that the burden should instead rest upon Parliament to rectify this issue as a matter of statutory amendment.

\section{$B$ Legislative Amendment}

A legislative amendment is the best method of reform because it would send a public signal of law change and provide the requisite certainty to enable commercial stakeholders more flexibility in deciding what collateral secures their obligations. It would also be consistent with international treatment of the issue and would remove the inconsistency between the New Zealand PPSA and its

127 Gedye, Cuming and Wood Personal Property Securities in New Zealand, above n 17, at 288-289.

128 Duggan "Romalpa Agreements Post-PPSA", above n 37, at 663-664; This is an example of what Charles Mitchell labels "reviving subrogation": see Charles Mitchell, The Law of Subrogation (Clarendon Press, Oxford, 1994) at 5.

129 Gedye, Cuming and Wood Personal Property Securities in New Zealand, above n 17, at 289.

130 Duggan "Romalpa Agreements Post-PPSA", above n 37, at 664.

131 Cuming and Wood, above n 97; Widdup, above n 2, at [17.39]; and Gault and others, above n 23, at 171.

132 Farrar and O'Regan, above n 31, at 11 (emphasis added). 
sibling PPSAs. It is suggested that the New Zealand Parliament should amend ss 16 and 73-75. The following amendments, based on the AuPPSA, are proposed:

\section{purchase money security interest-}

(a) means-

(i) a security interest taken in collateral by a seller to the extent that it secures the obligation to pay all or part of the collateral's purchase price; or

(ii) a security interest taken in collateral by a person who gives value for the purpose of enabling the debtor to acquire rights in the collateral, to the extent that the value is applied to acquire those rights; or

(iii) the interest of a lessor of goods under a lease for a term of more than 1 year; or

(iv) the interest of a consignor who delivers goods to a consignee under a commercial consignment; but

(b) does not include a transaction of sale and lease back to the seller

(c) does not lose its status as such only because the purchase money obligation is renewed, refinanced, consolidated or restructured (whether or not by the same secured party).

73 Priority of purchase money security interest in collateral or its proceeds, other than inventory or intangibles

(1) A purchase money security interest in collateral or its proceeds, other than inventory or intangibles, has priority over a non-purchase money security interest in the same collateral given by the same debtor if the purchase money security interest in the collateral or its proceeds is perfected not later than 10 working days after the day on which the debtor, or another person at the request of the debtor, obtained possession of the collateral, whichever is earlier or, in the case of refinance, before discharge of the previous PMSI obligation.

74 Priority of purchase money security interest in inventory or its proceeds

(1) A purchase money security interest in inventory or its proceeds has priority over a nonpurchase money security interest in the same collateral given by the same debtor if the purchase money security interest in the inventory or its proceeds is perfected at the time the debtor, or another person at the request of the debtor, obtains possession of the collateral, whichever is earlier_or, in the case of refinance, before discharge of the previous PMSI obligation.

\section{Priority of purchase money security interest in intangible or its proceeds}

(1) A purchase money security interest in an intangible or its proceeds has priority over a non-purchase money security interest in the same collateral given by the same debtor if 
the purchase money security interest in the intangible or its proceeds is perfected not later than 10 working days after the day on which the security interest in the intangible attached or, in the case of refinance, before discharge of the previous PMSI obligation.

It is suggested that the Canadian "deemed assignment approach" should not be followed because Samwise illustrates that the same results can be achieved through a simpler amendment. The jargon of "assignment" may also cause unnecessary confusion. However, unlike the AuPPSA, it is suggested that ss 73-75 explicitly state the period for perfection of refinanced PMSIs. This would remove any uncertainty arising from the express rejection of the Unisource approach to interpreting the existing perfection provisions in Jenkins. Consistent with the Saskatchewan Personal Property Security Act amendment, perfection should occur before discharge of the previous obligation so as to ensure notification of the new interest. However, s 77, which provides that priority is determined by s 66 as between perfected PMIS, will still apply. Accordingly, it may be that in refinancing, a secured party may lose its priority to prior perfected PMSIs.

\section{CONCLUSION}

The unalloyed good of PMSI refinance, consistent with the scheme of the PPSA to facilitate the provision of credit to business, should be recognised through the preservation of super-priority via legislative amendment of ss 16 and 73-75. Recognising super-priority in circumstances of PMSI refinance would align the law in New Zealand with comparable jurisdictions and encourage refinancing transactions and therefore competition in the lending marketplace. Recognising superpriority would not be prejudicial to prior-registered secured parties who were always subordinate to the original PMSI, and is consistent with the justifications for PMSI super-priority as encapsulated by static NMT and SMT. As a refinancier's right to super-priority would only be recognised where original PMSI was perfected, the amendment is consistent with the integrity of the PPSA priority system. 